\title{
Al margen
}

\section{LA ESCRITURA COMO MONTAJE. LIBRETAS 2016-2018}

\author{
Pablo Martínez Zárate \\ Universidad Iberoamericana CDMX, México \\ pablo.martinez@ibero.mx
}

$\mathrm{E}$ scribir es un acto de ocupación del mundo. Hacer visible el aliento, dar cuerpo a la voz, intervenir el curso del relato histórico. Escribir es hendir el tiempo al introducir nuestra mirada en el horizonte común —es reconocimiento de uno mismo y de la otredad-. Escribir no solo es usar el lenguaje escrito: escribir es tejer sentido con todas las herramientas que la sensibilidad e inteligencia humana tienen al alcance. En el proceso de la investigación artística la escritura deviene inevitable. Se introduce siempre de un modo u otro, con mayor o menor estructura, en uno u otro o casi siempre - varios soportes. En su condición de espejo, permite visualizar las ideas y ordenar su participación en un cuerpo de obra.

Al plantear a la escritura como montaje, no solamente evoco un interés profundo de mi parte por el montaje cinematográfico, sino también la búsqueda de un orden entre elementos que antes de intervenir carecen de este orden impuesto. Un reacomodo de la materia sensible o inteligible según una "nueva" inteligencia-sensibilidad que se apropia de ellos e impone una participación renovada de la realidad. Así, los procesos de escritura, al insertarse en una dinámica de investigación artística, se presentan como dinámicas de montaje donde el pensamiento y la sensibilidad van tejiendo sentido, muchas veces, incluso, fuera de lo aparente. 
En este espacio me permito compartir fragmentos de mis procesos de escritura muestras mínimas de las libretas escritas entre 2016 y 2018 - como calco de un territorio de encuentro, donde convergen las distintas facetas de mi práctica artística que, además de la escritura, involucra la realización audiovisual, el diseño de instalaciones y piezas interactivas, así como la fotografía experimental.

En las siguientes imágenes se da testimonio de distintos procesos de obra concluida y exhibida, como son los proyectos Estas imágenes son verdad. Microarchivo de la ignominia ${ }^{1}$ y Codex Cochinilla. ${ }^{2}$ En ambos casos, se utilizaron pigmentos de grana cochinilla preparados en el estudio sobre soportes fotográficos. Siendo que no encontré ninguna documentación sobre el uso de la cochinilla sobre materiales fotográficos - papeles y películas de cine y diapositivas-, el proceso implicó una prueba constante de diluciones y su observación detallada. En este caso, la escritura se entiende como un registro de procesos de investigación en su sentido más literal - prueba y error, observación y sistematización de resultados para la posterior presentación de una obra-. Al mismo tiempo, las siguientes imágenes dan testimonio de proyectos inconclusos - como una idea de un estudio escultórico para cine-, que son igualmente formativos en la definición de un cuerpo de investigación artística. Adicionalmente, las anotaciones libres sobre mi vida e ideas son como esos eslabones la mayoría de los casos invisibles al espectador que sostienen una práctica creativa en distintos soportes. Las anotaciones se entretejen con collages de documentos e imágenes recolectadas. En los últimos años, como dan cuenta estas libretas, he recurrido al dibujo suelto $-\mathrm{y}$ errático- . Si bien mis habilidades son bastante pobres, he encontrado en el trazo libre otra forma de contemplación del entorno, otro tiempo para la escritura.

Estas imágenes son una mirada mínima al soporte de mi producción, escrituras que son andamiaje de una práctica y un habitar, que son montaje - ordenamiento del sentido- de mis investigaciones artísticas. La creación es escritura. Si pierdo la escritura, pierdo mi ocupación.

1 Disponible en: http://pablomz.info/eisv

2 Disponible en: http://pablomz.info/å 

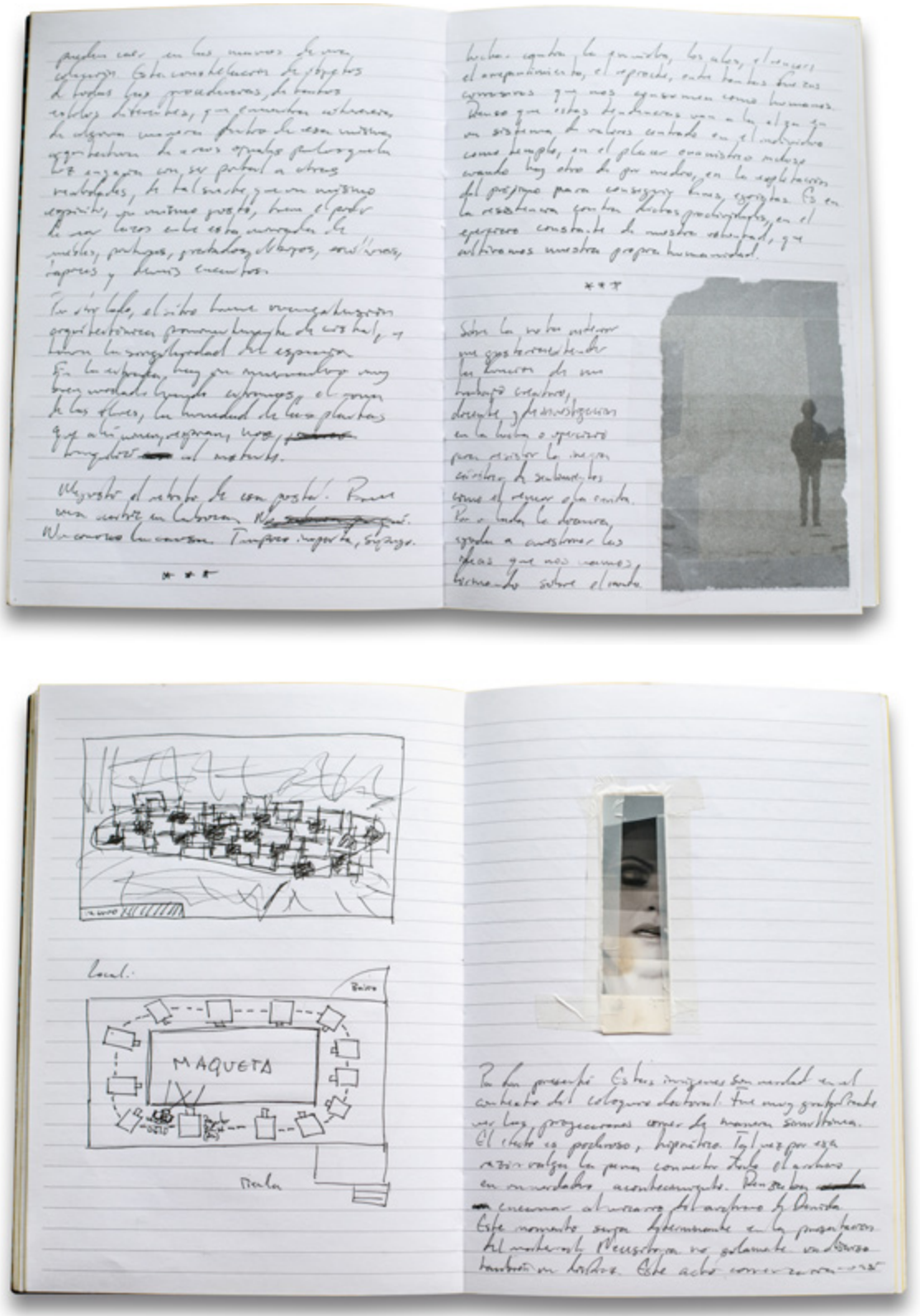

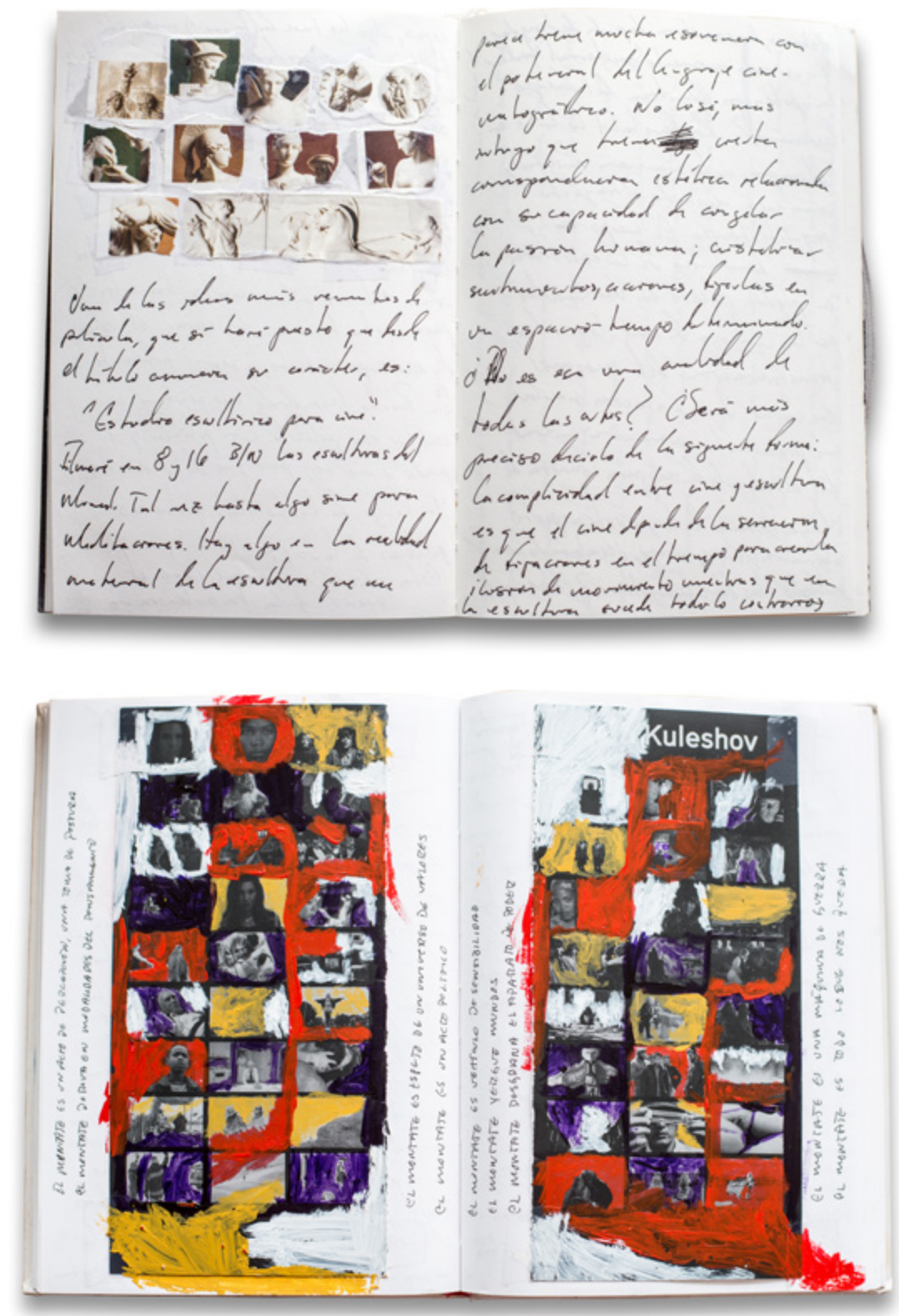

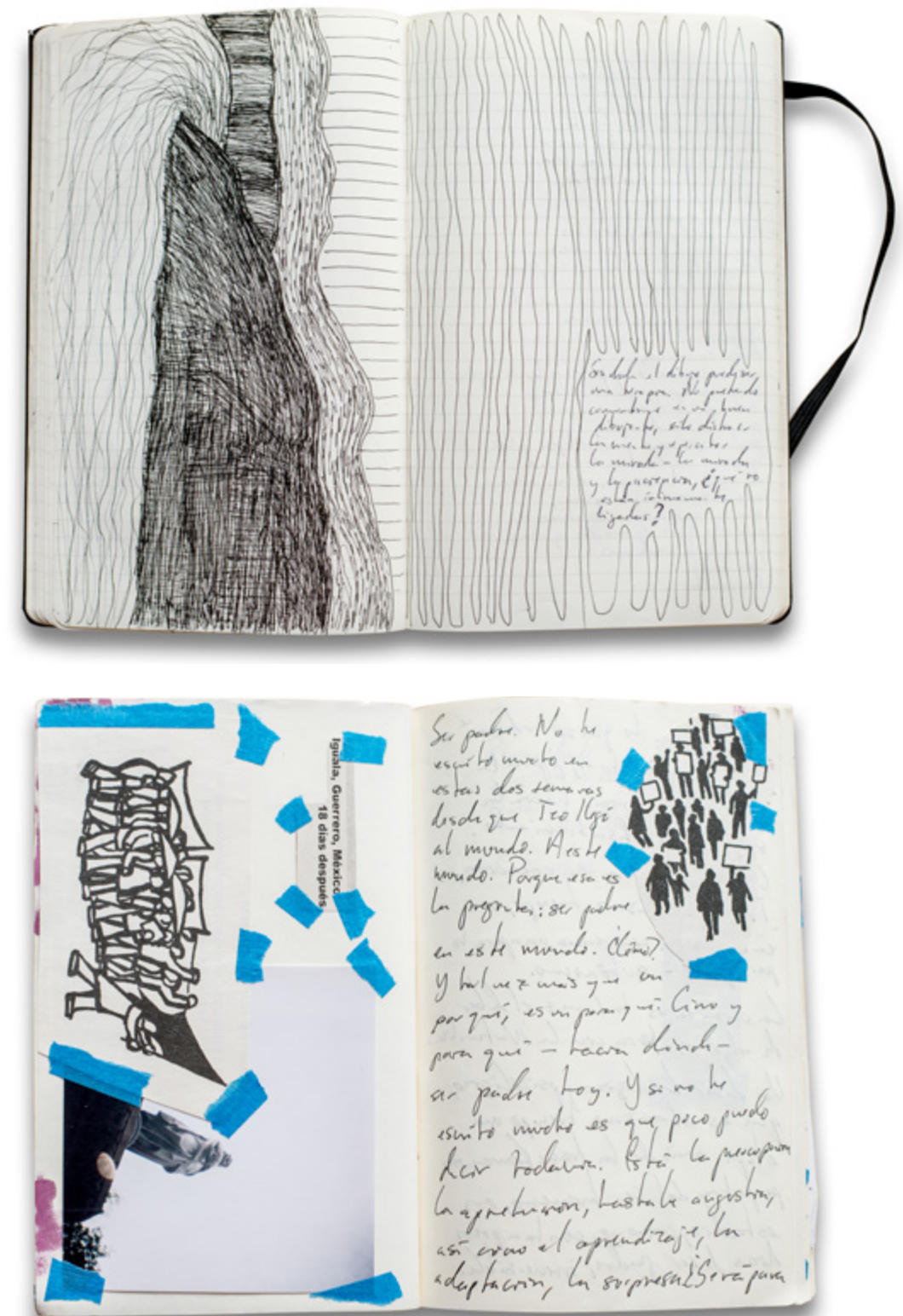
EL ORNITORRINCO TACHADO • No. 10 • México • UAEMéx • noviembre 2019 - abril 2020
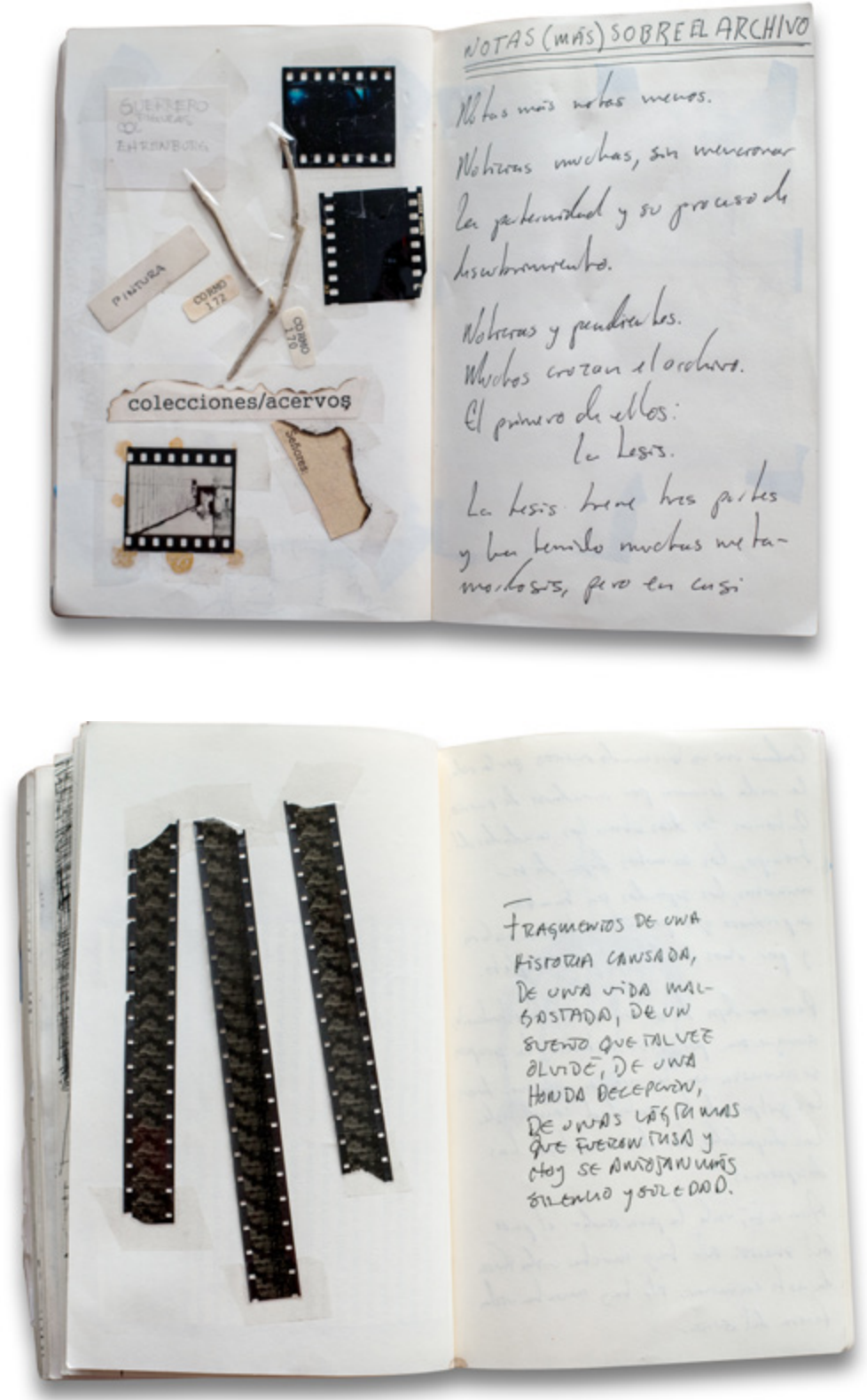
AL MARGEN • La escritura como montaje. Libretas 2016-2018 • PABLO MARTÍNEZ ZÁRATE

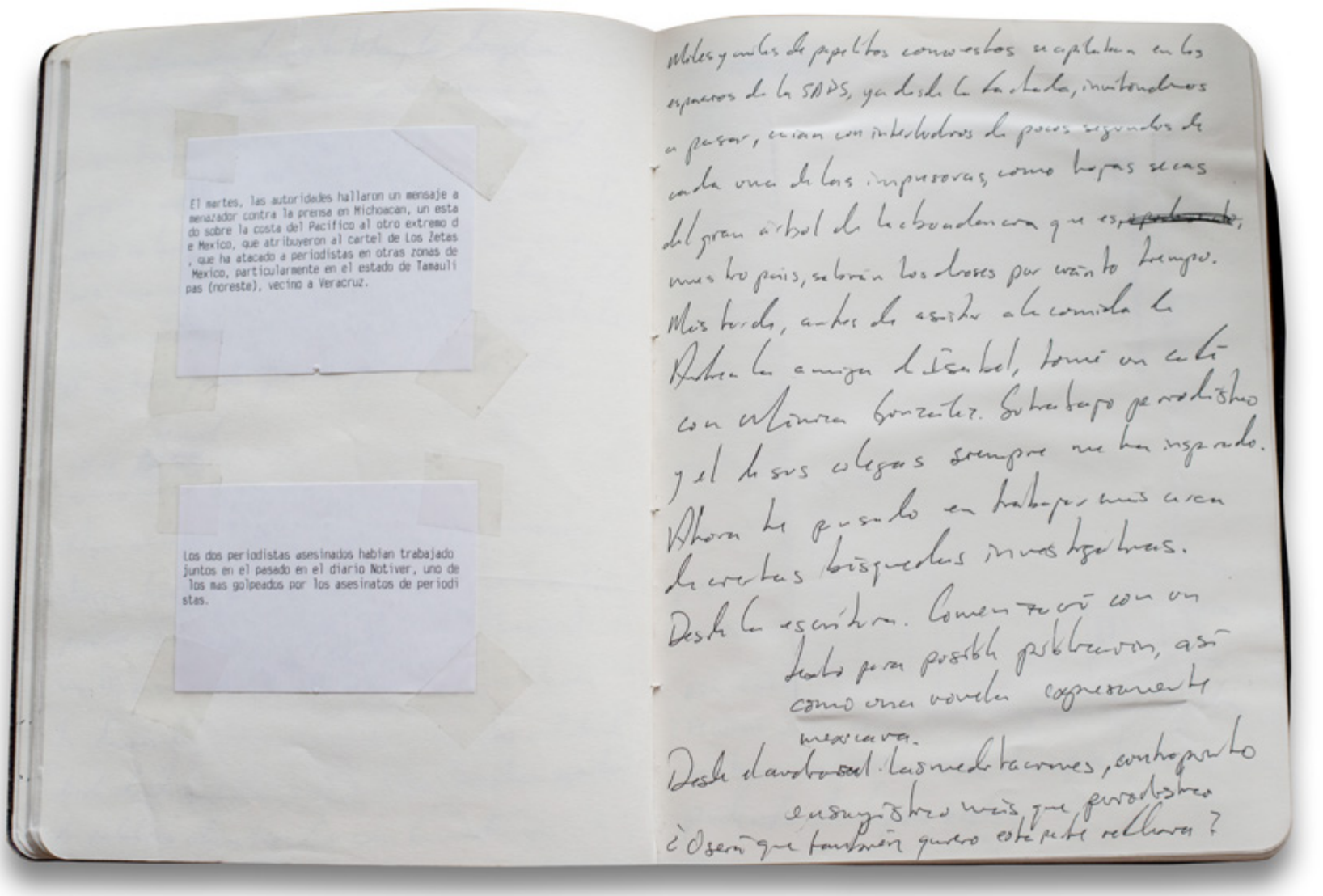

135 